\title{
Plant diversity in logged over forest in Mahakam Ulu, East Kalimantan, Indonesia
}

\author{
ADHY WIDYA SETIAWAN ${ }^{1,2, \boldsymbol{v}}$, ALBERTUS TJIU ${ }^{3}$, ARI MEIDIDIT $^{3}$ ISWINANTO $^{3}$, AMMAR GINANJAR ${ }^{3}$, \\ YOHANES ATUT ${ }^{3}$, RANDI AGUSTI ${ }^{1,4,5}$ \\ ${ }^{1}$ Forum Pohon Langka Indonesia. Jl. Ir. H. Juanda No. 18, Bogor 16122, West Java, Indonesia. ”email: adesahy@ gmail.com \\ ${ }^{2}$ Celebica, Perumahan Lo'Tauro Garden, Blok A. 4. Kota Palopo 91926, South Sulawesi, Indonesia \\ ${ }^{3}$ WWF Indonesia - Mahakam Kayan Project. Jl. Cut Nyak Meuthia No. 18 Barong Tongkok, Kutai Barat 75776, East Kalimantan, Indonesia \\ ${ }^{4}$ Integrated Tropical Peat Research Program, NUS Environmental Research Institute, T-Labs, National University of Singapore. 5A Engineering Drive 1, \\ Singapore 117411 \\ ${ }^{5}$ Natural Kapital Indonesia. Jl. Karna Sosial No. 88, Pontianak 78121, West Kalimantan, Indonesia
}

Manuscript received: 23 July 2021. Revision accepted: 17 October 2021.

\begin{abstract}
Setiawan AW, Tjiu A, Meididit A, Iswinanto, Ginanjar A, Atut Y, Agusti R. 2021. Plant diversity in logged over forest in Mahakam Ulu, East Kalimantan, Indonesia. Biodiversitas 22: 4829-4838. A study of flora was conducted in the Ratah Timber concession area. The objectives of this study were to calculate the Importance Value Index (IVI) and identify species diversity in Mahakam Ulu, East Kalimantan. A survey was carried out in 128 plots within 13 transects placed purposively. Vegetation sampling was conducted using line-transect and a quadrat method. As many as 530 species belonging to 79 families were found. Of these species, 420 species were found in observation plots with 374 of the species being trees. The most dominant tree species were Endertia spectabilis, Shorea pinanga and Shorea leprosula with IVI of $10.24 \%, 8.25 \%$, and $6.96 \%$, respectively. In total, 114 species or $21.5 \%$ are endemic species of Borneo. The Shannon-Wiener diversity index at tree level was 5.51 and at seedling level was 4.95. The highest Similarity Index was found between transects 23 and 21, meanwhile the lowest was between transects 05 and 15 . This study found 61 species that are classified on the International Union for Conservation of Nature (IUCN) Red List (2020-1) as critically endangered (16), endangered (11), and vulnerable (34) species.
\end{abstract}

Keywords: Borneo, diversity, endemic, flora

\section{INTRODUCTION}

Borneo is a source of biodiversity colonization in South East Asia (de Bruyn et al. 2014). Despite the absence of volcanoes, Borneo has a lot of substrate variations which are important in biodiversity evolution (de Bruyn et al. 2014; Yu et al. 2021). Borneo was considered by several studies as the center of diversification for multiple taxa (Nauheimer et al. 2012; Webb and Ree 2012) including the genus Artocarpus, making it an evolutionary biodiversity hotspot (Williams et al. 2017). Southeast Asian forests can be characterized by the ubiquity of Dipterocarpaceae (Aoyagi et al. 2012; Heckenhauer et al. 2018; Raes et al. 2014). The number of dipterocarps is the highest in Borneo Island (about 267 species) or Kalimantan (about 200 species) (Ashton 1982; Purwaningsih 2004). Occupying the Sunda Shelf in the Indo-Australian Archipelago and Southeast Asia region, Borneo sits astride the Equator (Husson et al. 2019). The island has a high degree of regional and local flora endemism (Lohman et al. 2011; von Rintelen et al. 2017; Wong 2011).

The basic forests ecology has to be understood in order to establish a sound forest management (Krisnawati et al. 2011). The lack of data suitable for conservation action priority setting often hampers conservation efforts targeting plant diversity (Darbyshire et al. 2017). Administratively, the island of Borneo is owned by three countries, namely
Indonesia, Brunei Darussalam and Malaysia. Kalimantan Angiospermae diversity is second only to Java, although the area of Borneo is larger than that of Java (Retnowati et al. 2019). The fact that numerous collaborative research loci of Indonesian flora were mostly in Java Island is among the reasons why the number of species in Java Island is higher than that in Borneo. The estimate of collection density in Borneo is much less than Java at a ratio of 35:199 collections per $100 \mathrm{~km}^{2}$ (Middleton et al. 2019). As a biodiversity hotspot, Borneo urgently needs effective conservation actions (Voigt et al. 2021). Basic biodiversity research that includes botanical explorations is one crucial activity that will help accelerate the planning and formulation of conservation plans in Borneo (Hairah et al. 2017; Sabran et al. 2014). One of the studies on botanical biodiversity is vegetation analysis. In Borneo, vegetation analysis for lowland trees in the whole island was conducted by Slik et al. (2003). However, the research was limited and did not include the Mahakam Ulu area in the sample. For this reason, the study of the unique lowland forests in Mahakam Ulu needs to be conducted. Therefore, the objectives of this study are to calculate the IVI and identify species diversity in Mahakam Ulu Forest. WWF Indonesia-Mahakam Kayan Project has conducted research in the Ratah Timber concession area. It is expected that the findings of this research will enrich the existing knowledge about forest formation type and provide a better 
understanding of its ecological values.

\section{MATERIALS AND METHODS}

\section{Study area}

A vegetation survey in the forest area of Ratah Timber concession was conducted from March 18 to April 7, 2020.
The survey was carried out in 13 transects placed purposively, expected that they could represent the whole concession area and every forest coverage. (Figure 1 and Figure 2). The composition of forest vegetation in the study area is mixed dipterocarp forest. This forest type normally grows and develops in dryland habitats, in areas with undulating topography like hills or mountains.
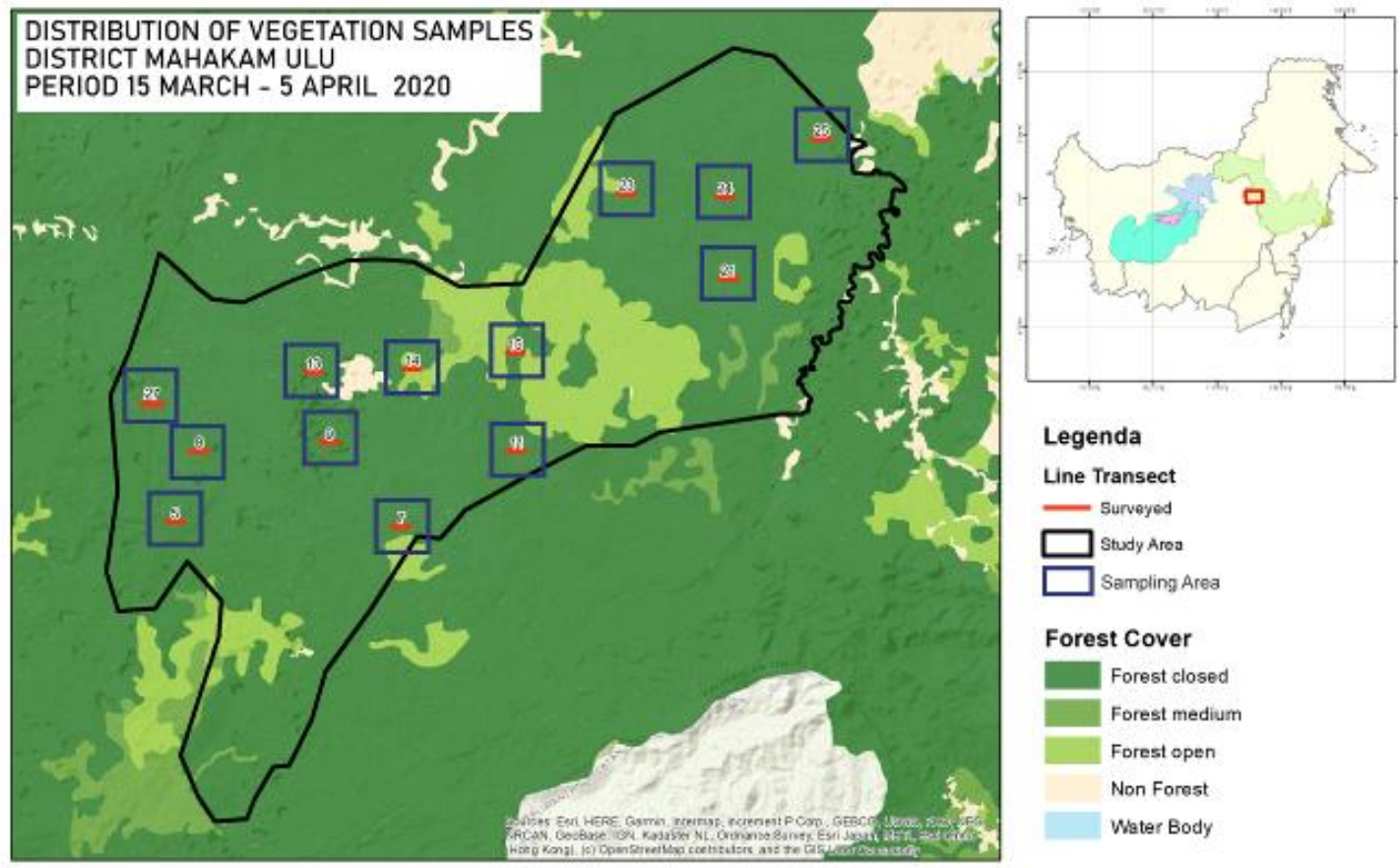

Forest Cover

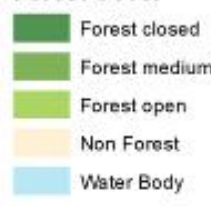

Figure 1. Plot samplings distribution map (blue square)
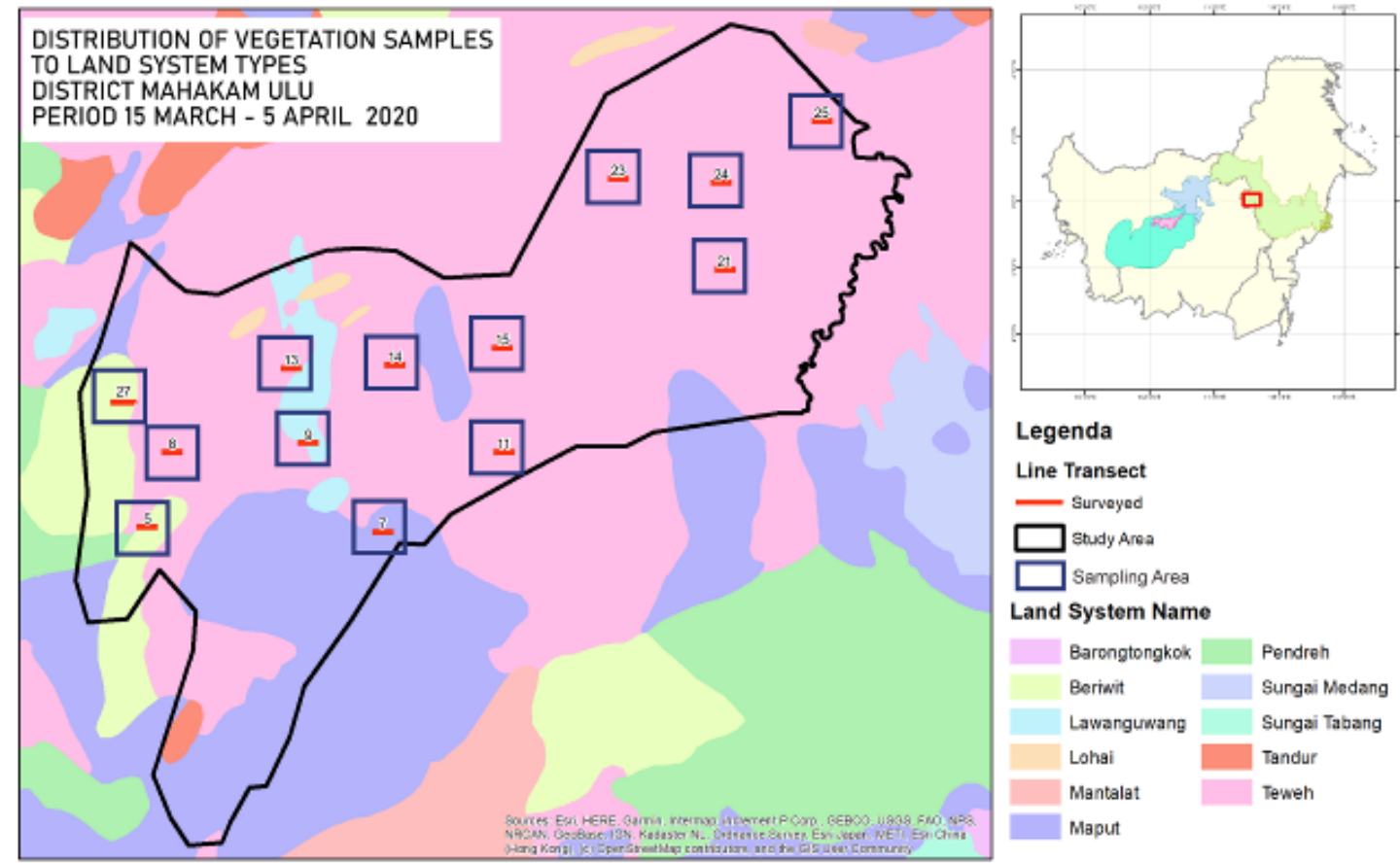

\section{Legenda}

Line Transect

- Survayed

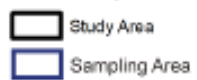

Land System Name

Barongtongkok Pendreh

Beriwit Sungai Medang

Lawanguwang

Lohs

Sungai Tabang

Tandur

Maput

Figure 2. Land system type distribution map (number with blue square) 


\section{Procedure}

Transects and plots

Transect lines were 1 kilometer $(\mathrm{km})$ long, comprising ten $20 \times 20 \mathrm{~m}$ vegetation plots, separated $100 \mathrm{~m}$ from each other. Objects observed were trees with a diameter at breast height (DBH / $1.3 \mathrm{~m}$ above ground) of $10 \mathrm{~cm}$ or more. Seedling sub-plots, on the other hand, were $2 \times 2 \mathrm{~m}$, placed to record seedling species and their number in each observation plot. (Figure 3 ). Seedling is a category of the woody plant (especially trees) growing to $\leq 1.5$ meters in height (Mansur 2011). Seedlings are recorded when they have 3-7 leaves and have fully extended outward or blossom to make it easier to distinguish the name of each species (Handayani et al. 2017).

The ecosystem type of the study site was determined by Kartawinata (2013) and described as field conditions. Specimen taxonomy identity was defined by local experts and published in the literature including the Flora Malesiana Series (1995-2012). Data literature/basics in networks like Plants of the World Online (Pelser et al. 2011; POWO 2019); Asian plant (Slik 2009) and Plant List (2019). Voucher specimens (including unidentified specimens) were stored in the herbarium of Wanariset Samboja for future reference. The global conservation status of all species collected in the field has been determined using the IUCN Red List (2020) and endemic tree species of Borneo (Sidiyasa 2015).

\section{Data analysis}

This study used a descriptive approach. Qualitative data analysis was conducted to determine ecosystem type and list all species in the ecosystem. Quantitative data analysis was carried out to study plant diversity, and parameters such as frequency, density, and important value index (IVI) of species were used. Parameters below were determined by Mueller-Dumbois and Ellenberg (1974).

Density $\left(D\right.$, tree $\left./ \mathrm{m}_{2}\right)=$ Number of individuals per species-area sampled
Relative Density $\left(R_{D}\right)=$ Density of a species x 100

Total density of all species

Frequency $(F)=$ Number of plots in which species exist Total number of plots sampled

Relative Frequency $(\mathrm{RF})=$

Frequency value for a species x 100

Total frequency for all species

Relative Dominance $\left(\mathrm{R}_{\mathrm{Do}}\right)=$

Total dominance of a species x 100

Total dominance of all species

Importance Value Index $(I V I)=R_{D}+R F+R_{D o}$.

To further assess the species diversity, Shannon Diversity index $\left(\mathrm{H}^{\prime}\right)$ was computed as follows (Krebs 1989):

$$
H^{\prime}=-\sum_{i}^{s}\left[\left(\frac{n i}{N}\right) \ln \left(\frac{n i}{N}\right)\right]
$$

Where: $\mathrm{n}$ is the proportion $(\mathrm{n} / \mathrm{N})$ of individuals of one particular species found and $\mathrm{N}$ is the total number of individuals found, $\Sigma$ is the sum of the calculations, and $\mathbf{s}$ is the number of species.

\section{Community Similarity Index}

Similarity Index (S) which points out at community similarity level between locations using Sørensen (Odum 1993) formulation:

ISs $=2 \mathrm{c} /(\mathrm{a}+\mathrm{b})$

Where:

ISs : Community commonality

$\mathrm{c}$ : Individuals of particular species in the study plot

$\mathrm{a}:$ the number of species in study plot a

$\mathrm{b}$ : the number of species in study plot $\mathrm{b}$

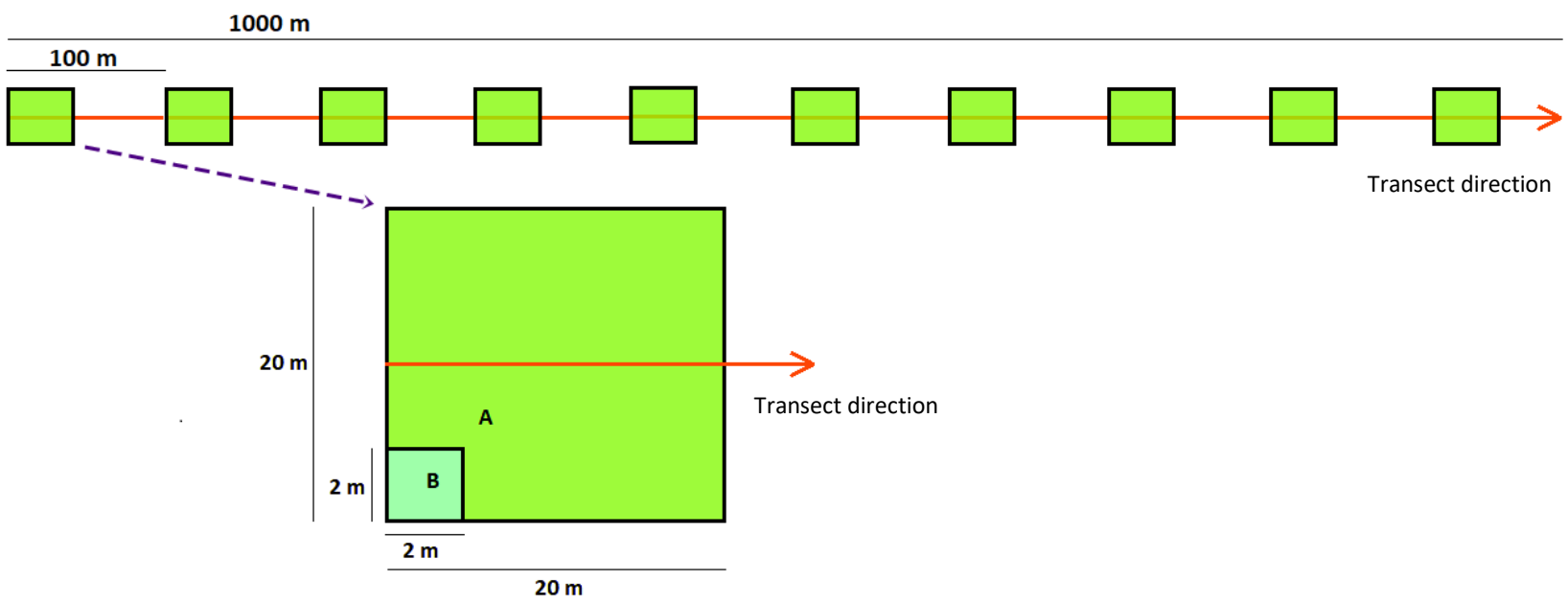

Figure 3. The design of vegetation transects and observation plots. Tree plot (A) with a size of $20 \times 20 \mathrm{~m}^{2}$ and seedling plot (B) with a size of $2 \times 2 \mathrm{~m}^{2}$ 


\section{RESULTS AND DISCUSSION}

\section{Description of ecosystem and field condition}

The topography of Ratah Timber concession, located in the lowland with an altitude of 50-300 meters above sea level, varies from flat, undulating hills to low cliffs. Based on its soil types and positions, the area being studied is made up of three ecosystems. They are Riparian, Dryland and Heath Forest. Field conditions are described below:

Riparian: A transitional area between water and land. The soil in the area contains water throughout the year, while flooding sometimes strikes as a result of fluctuations in river water discharge. Riparian ecosystem is common to the Ratah Timber Concession area, with good-condition forests along the bank of rivers of various sizes. Alluvial deposits cover a wide area in the eastern side of the concession, possibly resulting from Mahakam river sedimentation thousands of years ago. The alluvial deposits appear dark purple-black in color which is widely exposed during the soil excavation on the side of the concession road (a). Dryland: Evenly distributed throughout the concession, having a gentle topography, undulating to small hills with Red-Yellow Podzolic mineral soil conditions. Dryland is less likely to be inundated although flooding sometimes occurs due to river fluctuations. Located in the middle of the concession area, this dryland is obvious with hilly to cliffs and waterfalls topography. The composition of the rocks in the central area of the concession also differs from that in the eastern side which is made up of sedimentary and sandy rocks. The rock type in the center of the concession is basalt, an extrusive igneous rock originating from volcanic clots. Basalt rocks have a dark or pitch-black color which is clearly visible on the riverbed or cliffs in the center of the concession (b). Heath (Kerangas): Heath or Kerangas ecosystem is mainly characterized by the white sand substrate that makes it easily recognizable. Kerangas can also appear in higher land like hills/mountains. Unlike kerangas in a coastal area which is commonly flat with no rocks, chunks and sandy rock cliffs are often found in kerangas in higher areas. This condition is known as the sandstone ecosystem or sandy- rock ecosystem. In Ratah Timber Concession, kerangas or sandstone ecosystem is commonly found in the western side of the concession (c).

Table 1 below is the summary of the information in each observation transect, followed by a brief description of the field condition of each transect and the annual work plan (AWP).

\section{Diversity of plant species}

Despite the fact that some plants are not in great shape due to logging, Ratah Timber forest area has a pocket habitat that is considered important for plant diversity. The entire landscape of the Ratah Timber concession is remarkably diverse in plant species, as evidenced by the recorded 530 species with 79 families, inside and outside the plots. As many as 420 species were recorded within observation plots with 374 trees from 1588 individuals and 241 seedlings from 941 individuals. Overall, the family Dipterocarpaceae has the most common species (67 species), of which 35 species belong to Shorea (Figure 4).

Based on Figures 4 and 5, it is known that the number of species is not always directly proportional to the number of stems in the plot. The family Dipterocarpaceae had the most common species, with a total of 416 trees and 308 seedlings being recorded. The family Malvaceae, on the other hand, ranked second with 77 trees and 43 seedlings. In general, the average number of the tree is higher than that of seedlings, except for the families Euphorbiaceae and Rubiaceae. Arecaceae family, however, totaled 0 because rattan and palm were only included in the inventory but not counted in the plot.

\section{Threatened, protected and endemic species}

Direct observation of the sampling (13 transects and 128 observation plots) recorded 154 species classified as rare, endangered and endemic to Borneo (RTE). Table 2 summarizes the number of species based on the criteria of IUCN Red List, Appendix CITES, Distribution status of Borneo Endemic and national regulation.

Table 1. Summary of observation transect information

\begin{tabular}{lll}
\hline Transect ID & Field conditions & Rock formation \\
\hline WR-23 & Disturbed Primary Forest, AWP 2018 & Teweh \\
WR-24 & Primary Forest & Teweh \\
WR-14 & Disturbed Primary Forest, AWP 2016 & Teweh \\
WR-25 & Disturbed Primary Forest, AWP 2019 & Teweh \\
WR-21 & Disturbed Primary Forest, AWP 2009 & Teweh \\
WR-15 & Disturbed Primary Forest, AWP 2007 & Teweh \\
WR-11 & Disturbed Primary Forest, AWP 2013 \& 2017 & Teweh \\
WR-09 & Disturbed Primary Forest, AWP 1996-1993 & Lawanguwang \\
WR-07 & Disturbed Primary Forest, AWP 1996-1993 & Maput \\
WR-13 & Disturbed Primary Forest, AWP 1996-1993 & Lawanguwang \\
WR-05 & Primary Forest & Lohai \\
WR-08 & Disturbed Primary Forest, AWP 2000 & Teweh \\
WR-27 & Disturbed Primary Forest, AWP 2000 & Lohai \\
\hline
\end{tabular}

Note: WR: WWF-Ratah Timber Transect; AWP: Annual Work Plan for logging activities 


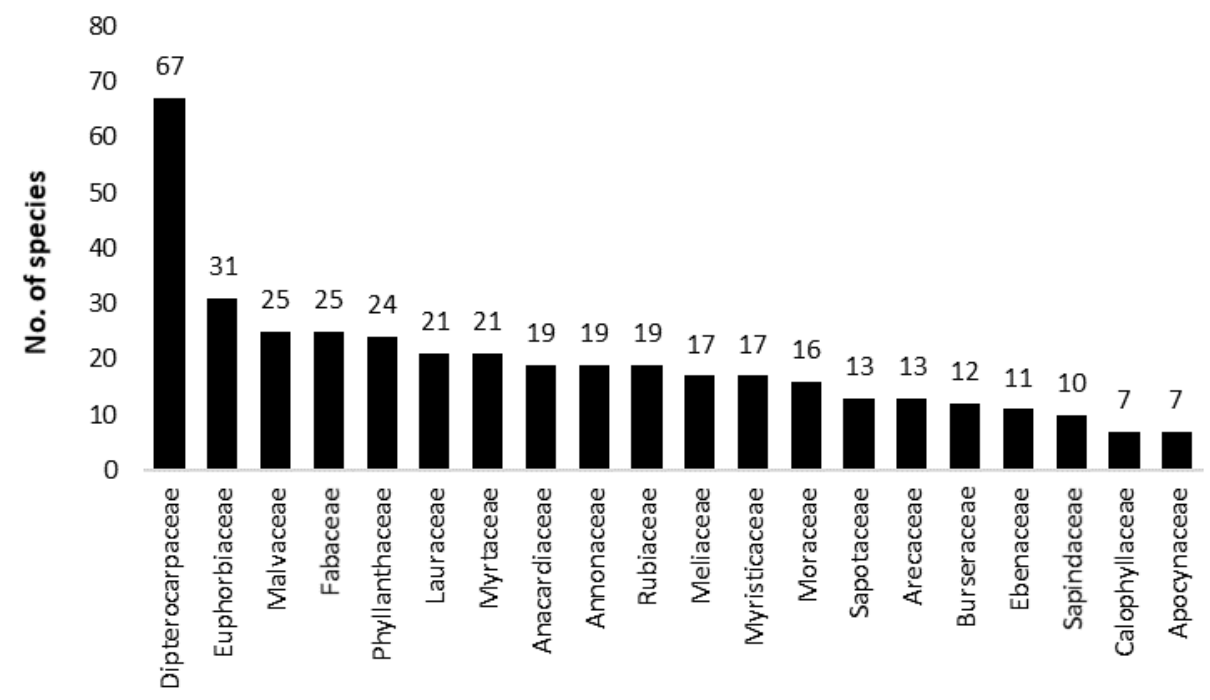

Figure 4. 20 families with the most recorded species

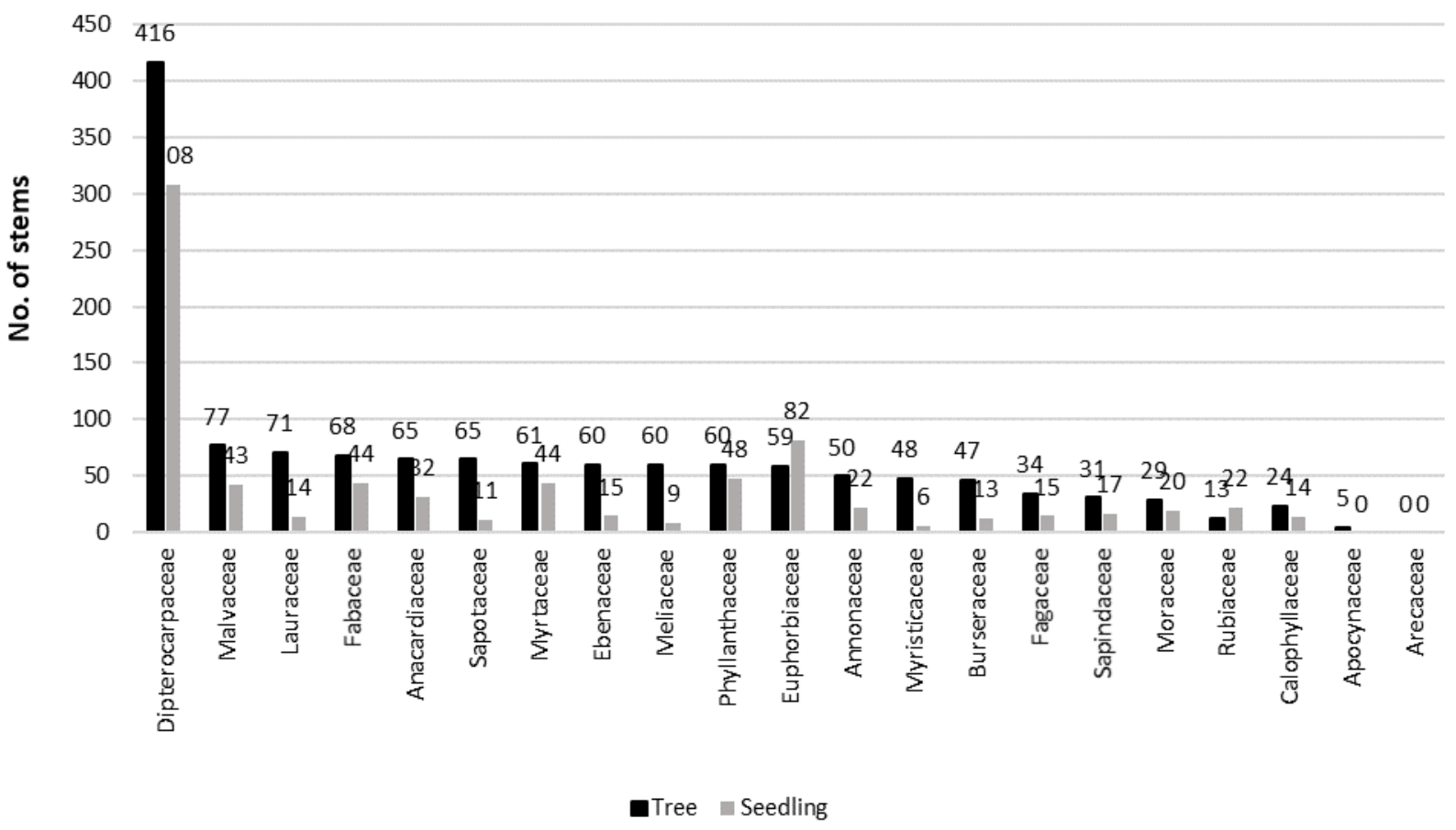

Figure 5. The proportion of stem number from 20 families with the most recorded species

Table 2. Summary of the number of RTE species found in agropolitan areas

\begin{tabular}{|c|c|c|}
\hline Status & Number of species & Explanation \\
\hline IUCN Red List & 61 & 16 Critically Endangered, 11 Endangered, 34 Vulnerable \\
\hline CITES & 8 & Appendix II \\
\hline Endemic & 114 & Exist in Borneo Only \\
\hline National Protection & 0 & Minister of Forestry Regulation 106/2018 \\
\hline
\end{tabular}


Tabel 3. Top 10 species with the highest Importance Value (IVI) at tree category

\begin{tabular}{llcccc}
\hline Rank & \multicolumn{1}{c}{ Species } & $\begin{array}{c}\text { RD } \\
(\%)\end{array}$ & $\begin{array}{c}\text { RF } \\
(\%)\end{array}$ & $\begin{array}{c}\text { RDo } \\
(\%)\end{array}$ & $\begin{array}{c}\text { IVI } \\
(\%)\end{array}$ \\
\hline 1 & Endertia spectabilis & 2.0781 & 1.6320 & 6.5341 & 10.2442 \\
2 & Shorea pinanga & 2.6448 & 2.3739 & 3.2293 & 8.2480 \\
3 & Shorea leprosula & 1.7632 & 1.6320 & 3.5714 & 6.9667 \\
4 & Shorea faguetiana & 1.3224 & 0.9644 & 3.4875 & 5.7743 \\
5 & Eusideroxylon zwageri & 1.3854 & 1.2611 & 2.7557 & 5.4022 \\
6 & Shorea parvifolia & 1.3854 & 1.1869 & 2.3773 & 4.9496 \\
7 & Shorea macroptera & 0.8816 & 0.8902 & 2.5969 & 4.3687 \\
8 & Shorea ovalis & 0.9446 & 0.8902 & 2.5158 & 4.3506 \\
9 & Vatica oblongifolia & 1.3224 & 1.1869 & 0.8077 & 3.3170 \\
10 & Parashorea melaanonan & 0.7557 & 0.8160 & 1.4287 & 3.0004 \\
\hline
\end{tabular}

Note: $\mathrm{R}_{\mathrm{D}}$ : Relative Density, RF: Relative Frequency, $\mathrm{R}_{\mathrm{Do}}$ : Relative Dominancy, IVI: Importance Value Index

Out of 61 species classified as threatened according to IUCN Red List, the Dipterocarpaceae family or the Shorea dominates the list with 16 species being classified as critically endangered(CR). Meanwhile, of 8 species are listed in CITES Appendix II, 5 are ramin species (Gonystylus spp.) and 3 are tropical pitcher plants (Nepenthes spp.). Moreover, a large number of Borneo endemic species were identified, and 114 species are only found in Borneo Island, including 21.5\% of 530 total plant species that were found. As to their status in national-scale protection, none of these species are listed in the Forestry Ministerial Regulation No. 106/2018. Two species, however, are included in the national priority tree species conservation strategy for 2019-2029, i.e., Durio oxyleanus and Shorea pinanga. Both are in Priority III, a widely distributed endemic species facing a high level of threat (Hamidi et al. 2019).

\section{Plot data analysis}

Sampling representation using 13 transects was done, with every transect having ten observation plots except transect WR-05 (8 plots only). There were a total of 128 plots in the sample. Landscape analysis shows that trees in the study area were relatively in good condition because logging was conducted selectively and Reduce Impact
Logging (RIL) was applied, minimizing damage in the forest to the lowest possible level.

\section{Importance Value Index (IVI)}

In the 5.12 ha-sample plots, 1,588 individual trees with a diameter of at least $10 \mathrm{~cm}$ were recorded, consisting of 374 species. Of all trees recorded, $99.20 \%$ of species could be identified while the other $0.80 \%$ tree species could be identified only to genus level. Mlaha or Buan (Endertia spectabilis) possessed the highest IVI and ranked first, followed by Tengkawang Pinang ( $S$. pinanga), Meranti Merah (Shorea leprosula), Meranti (Shorea faguetiana) and Ulin (Eusideroxylon zwageri) in the top five. Mlaha is not logged due to its low timber quality, while Tengkawang Pinang and Ulin are not logged for they are protected under the government regulations despite the fact that Ulin has been excluded from the list of protected plants issued in the latest regulation. It explains why these three large species had a significant number of individuals and were almost evenly distributed within the concession. The top ten trees were dominated by climax species without pioneer species domination. Some pioneer species found in the transects were Nasi-nasi (Callicarpa pentandra), Jabon (Neolamarckia cadamba), Terentang (Campnosperma auriculatum), Mahang (Macaranga pearsoni) and Medang (Litsea grandis) but were less dominant in the transects. The following is a summary of the ranking of the top 10 IVI at the species level (Table 3).

In the seedling category, a total of 941 individuals from 241 species were recorded from a total $512 \mathrm{~m}^{2}$ area. Of this number, $99.60 \%$ of seedling species could be identified, while $0.40 \%$ could be identified only to genus level. The species' IVI showed that dipterocarps clearly dominated the top five as two Meranti species ( $S$. leprosula and $S$. pinanga) ranked first and second, followed by two Kapur species (Dryobalanops lanceolata and D. oblongifolia) at the third and fifth places. This fact suggests that Ratah Timber forest has good potential for regeneration and shows promise as a mixed Dipterocarp lowland forest in the future. The following is a summary of the top 10 species according to their IVI at the seedling level (Table 4).

Tabel 5. Index Similarity of all research transects

\begin{tabular}{|c|c|c|c|c|c|c|c|c|c|c|c|c|c|}
\hline Transect & 23 & 24 & 14 & 25 & 21 & 15 & 11 & 9 & 7 & 13 & 5 & 8 & 27 \\
\hline 23 (AWP 2018) & 1 & & & & & & & & & & & & \\
\hline 24 (Primary Forest) & 0.35 & 1 & & & & & & & & & & & \\
\hline 14 (AWP 2016) & 0.38 & 0.36 & 1 & & & & & & & & & & \\
\hline 25 (AWP 2019) & 0.28 & 0.29 & 0.32 & 1 & & & & & & & & & \\
\hline 21 (AWP 2009) & 0.41 & 0.31 & 0.28 & 0.25 & 1 & & & & & & & & \\
\hline 15 (AWP 2007) & 0.32 & 0.31 & 0.28 & 0.19 & 0.36 & 1 & & & & & & & \\
\hline 11 (AWP 2013 \& 2017) & 0.34 & 0.36 & 0.23 & 0.18 & 0.32 & 0.31 & 1 & & & & & & \\
\hline 9 (AWP 1996-1993) & 0.27 & 0.15 & 0.24 & 0.17 & 0.20 & 0.23 & 0.26 & 1 & & & & & \\
\hline 7 (AWP 1996-1993) & 0.34 & 0.25 & 0.22 & 0.17 & 0.26 & 0.25 & 0.25 & 0.32 & 1 & & & & \\
\hline 13 (AWP 1996-1993) & 0.29 & 0.31 & 0.34 & 0.24 & 0.27 & 0.34 & 0.30 & 0.35 & 0.37 & 1 & & & \\
\hline 5 (Primary Forest) & 0.21 & 0.25 & 0.24 & 0.17 & 0.19 & 0.13 & 0.18 & 0.21 & 0.34 & 0.29 & 1 & & \\
\hline 8 (AWP 2000) & 0.36 & 0.22 & 0.23 & 0.14 & 0.28 & 0.37 & 0.31 & 0.32 & 0.36 & 0.32 & 0.21 & 1 & \\
\hline 27 (AWP 2000) & 0.33 & 0.30 & 0.24 & 0.24 & 0.36 & 0.36 & 0.29 & 0.26 & 0.27 & 0.35 & 0.22 & 0.35 & 1 \\
\hline
\end{tabular}

Note: Green color, the highest similarity value between plots. Blue color, the lowest similarity value between plots 
Table 4. Top 10 species with the highest Importance Value (IVI) in seedling category

\begin{tabular}{llcccc}
\hline Ranking & Species & Individual & $\mathbf{R}_{\mathbf{D}}(\boldsymbol{\%})$ & RF $(\boldsymbol{\%})$ & IV $(\boldsymbol{\%})$ \\
\hline 1 & Shorea leprosula & 38 & 4.0383 & 3.7702 & 7.8085 \\
2 & Shorea pinanga & 34 & 3.6132 & 2.6930 & 6.3062 \\
3 & Dryobalanops lanceolata & 33 & 3.5069 & 1.6158 & 5.1227 \\
4 & Leea amabilis & 21 & 2.2317 & 1.9749 & 4.2065 \\
5 & Dryobalanops oblongifolia & 29 & 3.0818 & 0.7181 & 3.8000 \\
6 & Swintonia acuta & 21 & 2.2317 & 1.0772 & 3.3089 \\
7 & Syzygium lineatum & 15 & 1.5940 & 1.6158 & 3.2098 \\
8 & Vatica oblongifolia & 13 & 1.3815 & 1.7953 & 3.1768 \\
9 & Mallotus minimifructus & 15 & 1.5940 & 1.2567 & 2.8508 \\
10 & Pternandra coerulescens & 13 & 1.3815 & 1.4363 & 2.8178 \\
\hline
\end{tabular}

Note: RD: Relative Density, RF: Relative Frequency, IV: Importance Value

\section{Diversity index}

The Shannon Weiner diversity index was 5.51 at the tree level and 4.95 at the seedling level. If seeds are found in large quantities, a parent tree will usually be found nearby. For example, D. lanceolata seedlings look like green expanses under the mother tree in several plots. When the survey was conducted, a lot of dipterocarps were fruiting and numerous seedlings grew simultaneously some of them are transect WR 05.

\section{Similarity Index}

Similarity Index is used to see similarities between communities and analyze the similarity statistically to determine the importance of forest type and disturbance. The community similarity index for both tree and seedling categories showed that transect 23 and transect 21 displayed the highest similarity value. The species composition was similar within the same forest type and/or with respective degrees of disturbance. Transect 23 is AWP 2018 and Transect 21 is AWP 2009. Both transects are at Teweh rock formation. Community similarity index was the lowest between transect 05 (hilly primary forest with sandstone community) and transect 15 , a secondary forest where tree logging occurred in 2007 and pioneer trees spread evenly all over the transects. Transect 05 stands on Lohai rock formation while transect 15 is on Teweh rock formation.

Similarity Index among vegetation transects demonstrates a strong variation on local scales. Various land formations and soil types have an impact on the plants community level in the study area. Structure, species composition and distribution of vegetation are greatly affected by soil (Kartawinata 2013). Borneo as part of central Sundaland is covered by sandy soils (Silk et al. 2011), resulting in vegetation types such as heath forest and peat and kerapah swamp forests (Raes et al. 2014). The formation of the rocks shows that the majority of plots are in Teweh land system, while other observation transects are located in Mentalat, Lohai, Lawanguwang, and Maput land systems (Table 1, Table 2, Figure 2). The Teweh land system occupies a hilly plain landform, covering $95 \%$ of the sloping area and 5\% of the peak, made up of sedimentary rocks. These rocks consist of sandstone and shale (RePPProT 1987). Igneous and metamorphic rocks have rock-forming minerals that contain most of the nutrients required by higher plants to grow and develop (Harley and Gilkes 2000). According to Widyasari et al. (2005), Mentalat land system has low N, P, K concentrations but high aluminum saturation, while Teweh land system has low $\mathrm{N}$ and $\mathrm{K}$ levels but high aluminum saturation. The nutrient content is a determining factor in the remarkably different species compositions between transect 05 and transect 15 based on the map in Figure 2 and the similarity index in Table 5 . Transect 05 was built upon a sandstone ecosystem, and no logging has ever been conducted here due to its limited wood potential. In transect 05 , there were not only epiphytes growing on low branches but also Nepenthes. These are the characteristics of the forest with low nutrients. In transect 15, commercial tree species were logged and then abandoned, allowing a succession process to occur. Documentation of dipterocarp in dryland lowland forest and sandstone forest being studied can be seen in Figure 6.

Geological history may be an external factor, in addition to physical barriers, that hinder dispersal or biotic interactions (Bruchmann and Hobohm 2014). Forest dynamics along the secondary forest to primary forest logged from 1993 to 2019 also contribute to the floristic composition. Some pioneer species such as $C$. auriculatum are very small to affect beta diversity because these pioneer species have a narrow habitat range and abundance. Pioneer species are ubiquitous and normally grow on diverse habitats, yet potentially reduce diversity (Yano et al. 2021). Macaranga spp. is tolerant species that can grow in barren soil such as the main road that has been cleared (Aoyagi et al. 2013; Yano et al. 2021). According to Aoyagi et al. (2013), not many dipterocarp species are able to live under the shade of Macaranga spp. because the decomposition process of $\mathrm{N}$ and $\mathrm{P}$ elements is too fast. Increase in Macaranga spp. patches can lead to forest floor degradation and prolonged primary forest damage. In Ratah Timber, pure Macaranga spp. patches were never found in the transects. The number of species per unit number of stems (species richness) was higher in the RIL than in conventional logging forest and the community composition of the RIL forest was more similar with primary forest than conventional logging (Imai et al. 2012). The RIL process in Ratah Timber concession allows young 
dipterocarp and non-dipterocarp plants to keep growing and regeneration of dipterocarp trees to take place at the site. Logging of certain species of trees with sufficient rotation time will minimize the damage of the forests and give time for the pioneers and the seedlings to compete and regrow into undamaged forests.

Landform also affects species composition in a community. In this research, tree species like Keruing (Dipterocarpus verucosus), Merawan (Hopea dryobalanoides) and Meranti/Tengkawang (Shorea beccariana) were generally found in mountain ridges while Shorea parvifolia, S. leprosula, S. faguetiana dan $S$. Pinanga grow in a rather sloping area.

Mahakam River and its deltas were formed in the early Miocene, when Australia collided with the eastern boundary of Sundaland (de Bruyn et al. 2014). Generally, rivers in Ratah Timber Concession display a dendritic pattern. It means that when the rain pours all over the river flow area, and flood peak will be so high that it will inundate the whole area around the river basin, especially in the downstream area. This floodplain was found at the beginning of transect 09 on the Nyaribungan River. At the beginning of transect 09, a lot of tree species with knee roots, breathing roots and taproots were found, and such roots are parts of plant's adaptation to their habitat. The plot was dominated by white sapped trees from Euphorbiaceae family (Blumeodendron kurzii, Blumeodendron tokbrai, Elateriospermum tapos), Sapotaceae (Payena lucida, Madhuca costulata, Palaquium beccarianum, Palaquium sericeum), and Apocynaceae (Dyera costulata, Alstonia angustiloba). A species with buttressed roots belonging to Anacardiaceae family (Swintonia acuta) was also found. Plants adapt to their habitat and occupy the niches to play their role in that certain habitat. This process has occurred for a really long time and has formed the structures and compositions of today's vegetation. In the wet area of the transects, wild palms like Pinanga albescens and Pinanga auriculata were also found. Although not included in the calculation analysis, the presence of Pinanga is an important record of biodiversity. Indonesia's palm diversity is the highest in the world, and $53 \%$ of the plants are endemic (Widyatmoko 2018). Genus Pinanga Blume spreads from the Himalayas and South China to New Guinea; however, the greatest diversity in the wet areas is found in Sunda Shelf (Agusti et al. 2019). Forty species of Pinanga grow in Borneo (Govaerts et al. 2018).

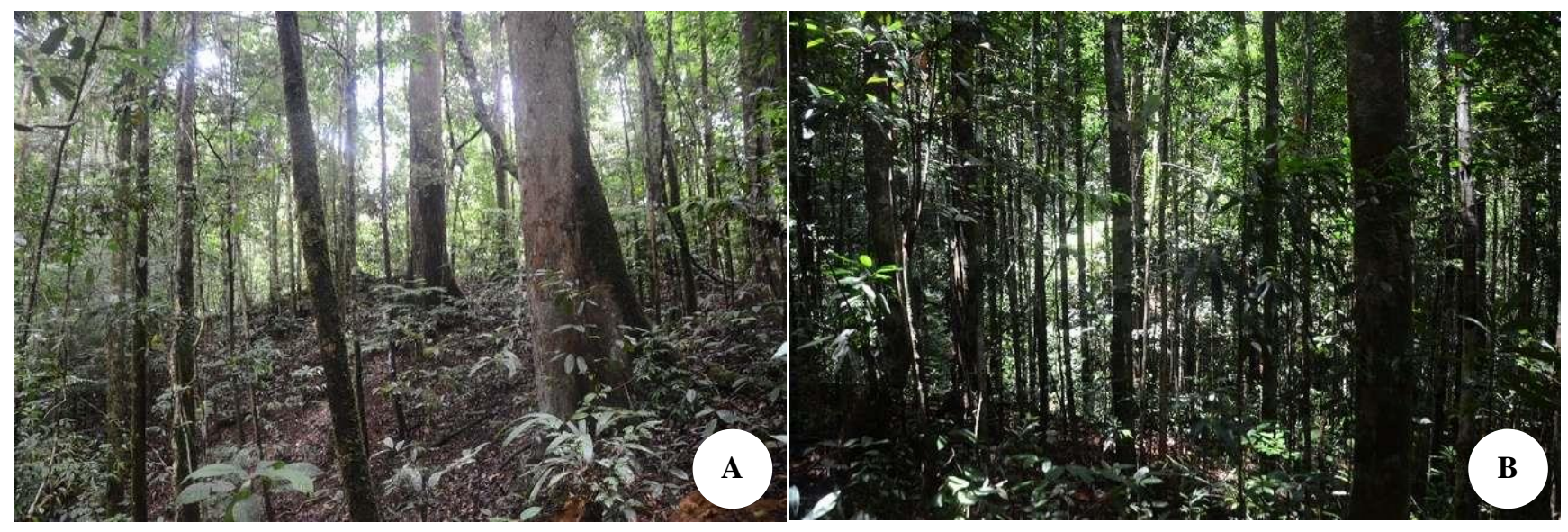

Figure 6. A. Condition of lowland forest, B. Heath forest in Ratah Timber Concession
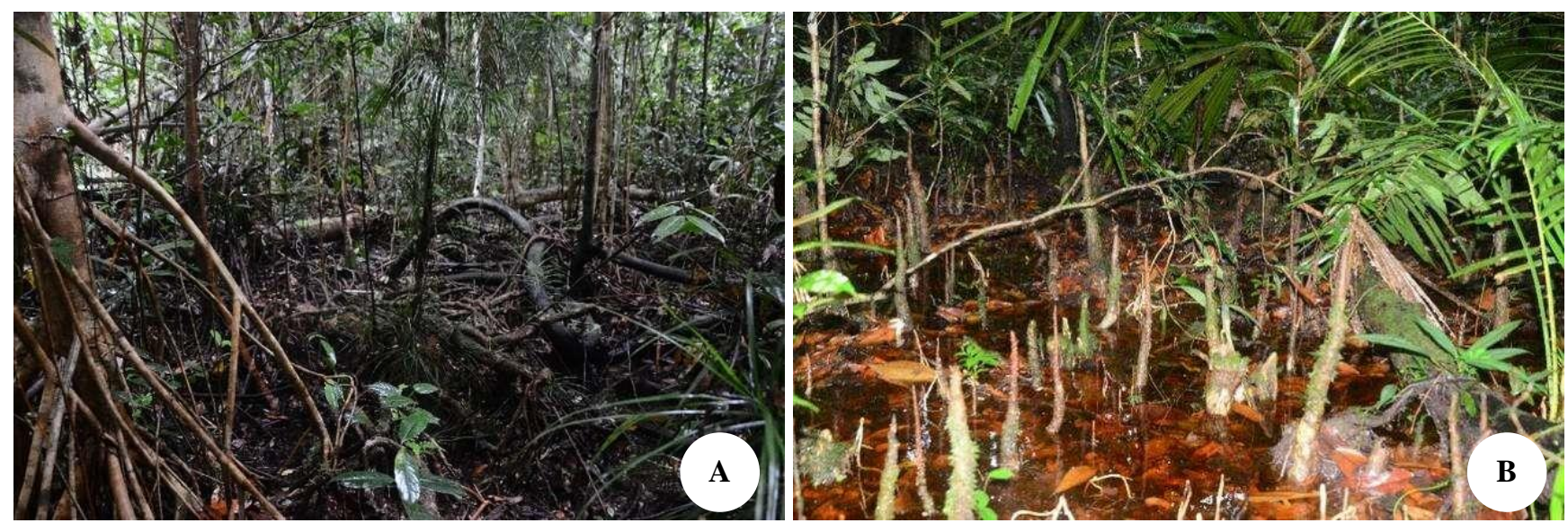

Figure 6. Root systems in the swampy area on the plot observations. A. Stilt roots, B. Pencil roots 
Borneo is home to 65 vascular plants genera from 25 families considered endemic to Borneo (Neo et al. 2020). Mlaha's findings reinforce that Borneo is unique as a biodiversity hotspot. Mlaha or Buan tree in local name ( $E$. spectabilis) is special because it is monotypic, meaning there is only single species in the genus, and thus far the only known genera and species of the endemic tree of Borneo grows in two areas, East Borneo and South Borneo (Neo et al. 2020).

Diversity is high when the dominance of a species over the plot/study area is low, with an importance value of the vegetation being less than 10 for both trees and seedlings. Hilly lands and several cuts by rivers are the uniqueness of Mahakam Ulu study area. Individual and species population levels are dynamic and they have changed continuously throughout time (Krisnawati et al. 2011). The diversity of seedlings was less valuable in primary forests due to factors like predation and competition (Aoyagi et al. 2013).

Borneo is a large island with great physiography and environmental heterogeneity that can promote the availability of many niche spaces, facilitating possible speciation and providing more area for species to persist during historical global climatic fluctuations (Stein et al. 2014). The result of this research is just a small part of a bigger unsolved mystery in Borneo forests, besides the discovery of medicinal substances and other resources that can provide ecological values to support human well-being in the future. Forest in Ratah Timber Concession area has to be conserved to produce sustainable benefits for all living organisms in the future.

Ratah Timber concession generally covers a forest area with various conditions ranging from bushes to untouched primary forest. Located in the lowland and dominated by Dipterocarpaceae species, the forest is also called as Lowland Mixed Dipterocarp forest. The diversity of plant species in the area can be categorized as very high with 530 plant species being recorded both inside and outside the observation plots. The high level of plant diversity is caused by a combination of several important factors such as types of ecosystem, land cover, topography, altitude, soil and rock types, rainfall, humidity, location and threats to forests. A total of 154 species of all listed species are classified as rare, threatened and endemic, while 16 species are classified as Critically Endangered. Mlaha or Bulan in a tree in local terms (E. spectabilis) is the most dominant tree species based on the analysis of IVI. Meanwhile, the most dominant species in the seedling category was Meranti Merah (S. leprosula).

\section{ACKNOWLEDGEMENTS}

The Researchers would like to thank WWF Sweden for funding this research, WWF Indonesia - Mahakam Kayan Project and Ratah Timber Concession that was supporting and organizing, as well as providing the data and information to complete and finish it. We also thank the Management of Herbarium of Wanariset Samboja, East Kalimantan for storing voucher specimens for future reference.

\section{REFERENCES}

Agusti R, Hikmat A, Haetubun CD. 2019. Pinanga schwanerensis, a new species of Pinanga (Arecaceae) from Kalimantan, Indonesia. Phytotaxa 402 (2): 121-125. DOI: 10.11646/phytotaxa.402.2.6.

Aoyagi K, Tsuyuki S, Phus MH, Teo S. 2012. Mapping distribution of Dipterocarpus in East Kalimantan, Indonesia. J For Environ Sci 28 (3): 179-184. DOI: 10.7747/JFS.2012.28.3.179.

Aoyagi R, Imai N, Kitayama K. 2013. Ecological significance of the patches dominated by pioneer trees for the regeneration of dipterocarps in a Bornean logged-over secondary forest. For Ecol Manag 289: 378-384. DOI: 10.1016/j.foreco.2012.10.037.

Ashton PS. 1982. Dipterocarpaceae. Flora Malesiana-Series 1, Spermatophyta 9 (1): 237-552.

Bruchmann I, Hobohm C. 2014. Factors that create and increase endemism. In: Hobohm C (ed) Endemism in Vascular Plants. Springer, Netherlands. DOI: 10.1007/978-94-007-6913-7.

CITES. 2014. Appendices I, II and III. www.cites.org/eng/app/appendices.php.

Darbyshire I, Anderson S, Asatryan A, Byfield A, Cheek M, Clubbe C, Ghrabi Z, Harris T, Haetubun CD, Kalema J, Magassouba S, McCarthy B, Milliken W, Montmollin Bd, Lughadha EN, Onana JM, Saidou D, Sarbu A, Shrestha K, Radford EA. 2017. Important plant areas: revised selection criteria for a global approach to plant conservation. Biodivers Conserv 26: 1767-1800. DOI: 10.1007/s10531-017-1336-6.

de Bruyn M, Stelbrink B, Morley RJ, Hall R, Carvalho GR, Cannon CH, Bergh GVD, Meijaard E, Metcalfe I, Boitani L, Maiorano L, Shoup R, Rintelen TV. 2014. Borneo and Indochina are major evolutionary hotspots for Southeast Asian biodiversity. Syst Biol 63 (6): 879-901. DOI: $10.1093 /$ sysbio/syu047.

Govaerts R, Dransfield J, Zona S, Hodel DR, Henderson A. 2018. World Checklist of Arecaceae. Royal Botanic Gardens. wcsp.science.kew.org.

Hairah U, Tejawati A, Budiman E, Agus F. 2017. Borneo biodiversity: Exploring endemic tree species and wood characteristics. ICSITech. DOI: 10.1109/ICSITech.2017.8257152.

Hamidi A, Yulita KS, Kalima T, Randi A. 2019. Strategi Konservasi 12 Spesies Pohon Prioritas Nasional 2019-2029. LIPI Press, Bogor. [Indonesian]

Handayani T, Wawaningrum H, Wihermanto, Yuzammi, harto Latifah D. 2017. Identifikasi Semai Tumbuhan Berkayu. LIPI Press, Jakarta. [Indonesian]

Harley AD, Gilkes RJ. 2000. Factors influencing the release of plant nutrient elements from silicate rockpowders: a geochemical overview. Nutr Cycling Agroecosyst 56 (1): 11-36. DOI: 10.1023/A:1009859309453.

Heckenhauer J, Samuel R, Ashton PS, Salim KA, Paun O. 2018. Phylogenomics resolves evolutionary relationships and provides insights into floral evolution in the tribe Shoreeae (Dipterocarpaceae). Mol Phylogen Evol 127: 1-13. DOI: 10.1016/j.ympev.2018.05.010.

Husson L, Boucher FC, Sarr AC, Sepulchre P, Cahyarini SY. 2019. Evidence of Sundaland's subsidence requires revisiting its biogeography. J Biogeogr 47 (4): 843-853. DOI: 10.1111/jbi.13762.

Imai N, SeinoT, Aiba Si, Takyu M, Titin J, Kitayama K. 2012. Effects of selective logging on tree species diversity and compossition of Bornean tropical rain forests at different spatial scales. Plant Ecol 213 (9): 1413-1424. DOI 10.1007/s11258-012-0100-y.

IUCN. 2016. The IUCN Red List of Threatened Species. Version 2014.3. www.iucnredlist.org.

Kartawinata. 2013. Indonesia's natural ecosystem diversity. A short phrase with a photo and picture presentation. LIPI Press \& Yayasan Pustaka Obor Indonesia, Jakarta. [Indonesian]

Krebs C. 1989. Ecological Methodology. Harper and Row, New York.

Krisnawati H, Wahjono D, Imanuddin R. 2011. Changes in the species composition, stand structure and aboveground biomass of a lowland dipterocap forest in Samboja, East Kalimantan. Indones J For Res 8 (1): 1-16. DOI: 10.20886/ijfr.2011.8.1.1-16.

Lohman DJ, Bruyn Md, Page T, Rintelen Kv, Hall R, Ng PKL, Shih HT, Carvalho GR, Rintelen TV. 2011. Biogeography of the IndoAustralian Archipelago. Annu Rev Ecol Evol Syst 42: 205-26. DOI: 10.1146/annurev-ecolsys-102710-145001.

Mansur. 2011. Teknik silvikultur untuk reklamasi lahan bekas tambang. Southeast Asian Regional Centre for Tropical Biology, Biotrop, Bogor. [Indonesian] 
Middleton DJ, Armstrong K, Baba Y, Balslev H, Chayamarit K, Chung RCK, Conn BJ, Fernando ES, Fujikawa K, Kiew R, Luu HT, Aung MM, Newman MF, Tagane S, Tanaka N, Thomas DC, Tran TB, Utteridge TMA, van Welzen PC, Widyatmoko D, Yahara T, Wong KM. 2019. Progress on Southeast Asia's flora projects. Gard Bull Sing 71 (2): 267-319. DOI: 10.26492/gbs71(2).2019-02.

Mueller-Dumbois D, Ellenberg H. 1974. Aims and Methods of Vegetation Ecology. John Wiley \& Sons, New York.

Nauheimer L, Boyce PC, Renner SS. 2012. Giant taro and its relatives: a phylogeny of the large genus Alocasia (Araceae) sheds light on Miocene floristic exchange in the Malesian region. Mol Phylogen Evol 63 (1): 43-51. DOI: 10.1016/j.ympev.2011.12.011.

Neo L, Wong KM, Tan HTW. 2020. A synopsis of the endemic plant genera of Borneo. Nordic J Bot 38 (9). DOI: 10.1111/njb.02871.

Odum EP. 1993. Dasar-Dasar Ekologi Edisi Ketiga. Gadjah Mada University Press, Yogyakarta.

Pelser PB, Barcelona JF, Nickrent DL. 2011. Co's Digital Flora of the Philippines. http://www.philippineplants.org.

POWO. 2019. Plants of the World Online. Royal Botanic Garden. www.plantsoftheworldonline.org.

Purwaningsih. 2004. Review: Ecological distribution of Dipterocarpaceae species in Indonesia. Biodiversitas 5 (2): 89-95. DOI: 10.13057/biodiv/d050210.

Raes N, Cannon CH, Hijmans RJ, Piessens,Saw LG, Welzen PCv, Silk JWF. 2014. Historical distribution of Sundaland's Dipterocarpra in forests at Quaternary glacial maxima. Proc Nat Acad Sci 111 (47): 16790-16795. DOI: 10.1073/pnas.1403053111.

RePPProT. 1987. Review of Phase I Result East and South Kalimantan. Jakarta. [Indonesian]

Retnowati A, Rugayah, Rahajoe JS, and Arifani D. 2019. Status Keanekargaman Hayati Indonesia: Kekayaan Jenis Tumbuhan dan Jamur Indonesia. LIPI Press, Jakarta. [Indonesian]

Sabran S, Nilus R, Pereira JT, Sugau JB. 2014. Contribution of the hearth of Borneo (HoB) initiative towards botanical exploration in Sabah, $\begin{array}{lllll}\text { Malaysia. } & \text { Reindwardtia } 14 & (1): & 137-142 . & \text { DOI: }\end{array}$ 10.14203/reinwardtia.v14i1.406.

Slik JWF. 2009. Plants of Southeast Asia. www.asianplant.net.

Slik JWF, Poulsen AD, Ashton PS, Cannon CH, Eichorn KAO, Kartawinata K, Lanniari I, Nagamasu H, Nakagawa M, van Nieuwstadt MGL, payne J, Purwaningsih, Saridan A, Sidiyasa K, Verburg RW, Webb CO, Wilkie P. 2003. A floristic analysis of the lowland dipterocarp forests of Borneo. J Biogeography 30 (10): 1517 1531. DOI: 10.1046/j.1365-2699.2003.00967.x.

Stein A, Gerstner K, Kreft H. 2014. Environmental heterogeneity as a universal driver of species richness across taxa, biomes and spatial scales. Ecol Lett 17 (7): 866-880. DOI: 10.1111/ele.12277.

The Plant List. 2013. Version 1.1. www.theplantlist.org.

Voigt M, Kuhl HS, Ancrenaz M, Gaveau D, Meijaard E, Santika T, Sherman J, Wich SA, Wolf F, Struebig MJ, Pereira HM, Rosa IMD. 2021. Deforestation projections imply range-wide population decline for critically endangered Bornean orangutan. BioRxiv. DOI: 10.1101/2021.07.16.451448.

von Rintelen K, Arida E, Häuser C. 2017. A review of biodiversity-related issues and challenges in megadiverse Indonesia and other Southeast Asian countries. Res Ideas Outcomes 3: e20860. DOI: 10.3897/rio.3.e20860.

Webb CO, Ree R. 2012. Historical biogeography inference in Malesia. In: Gower D, Johnson K, Richardson J, Rosen B, Ruber L, Williams S (eds) Biotic Evolution and Environmental Change in Southeast Asia. Cambridge University Press, Cambridge.

Widyasari D, Ruhiyat D, Sutisna M. 2005. Evaluasi kesesuaian lahan untuk beberapa jenis tanaman HTI pada areal rehabilitasi hutan bekas kebakaran PT ITCI Kartika Utama. Jurnal Kehutanan Universitas Mulawarman 12-24. [Indonesian]

Widyatmoko D. 2018. Conservation Strategy and Innovation of Indonesian Plants to Reduce the Extinction Rate. Inaugural Speech of Research Professor in the Field of Conservation and Environmental Management. LIPI Press, Jakarta. [Indonesian]

Williams EW, Gardner EM, Haris R, Chaveerach A, Pereira JT, Zerega NJC. 2017. Out of Borneo: biogeography, phylogeny and divergence date estimates of Artocarpus (Moraceae). Ann Bot 119 (4): 611-627. DOI: $10.1093 / \mathrm{aob} / \mathrm{mcw} 249$.

Wong KM. 2011. A biogeographic history of Southeast Asian rainforests. In: Wickneswari R, Cannon C (eds) Managing the future of Southeast Asia's valuable tropical rainforests. Springer, Dordrecht. DOI: 10.1007/978-94-007-2175-3_2.

Yano S, Aoyagi R, Shogoro F, Sugau JV, Pereira JT, Kitayama K. 2021. Effect of logging on landscape-level tree diversity across an elevational gradient in Bornean tropical forests. Glob Ecol Conserv 29: e01739. DOI: 10.1016/j.gecco.2021.e01739.

Yu TY, Turner IM, Cheek M. 2021. Revision of Chassalia (RubiaceaeRubioideae-Palicoureeae) in Borneo, with 14 new species. Eur J Taxon 738: 1-60. DOI: 10.5852/ejt.2021.738.1261. 